\title{
デマンドバス配車配送計画の実用的解法*
}

\section{A Practical Approach to Demand Bus Routing Problem *}

松本修一**・國府方久史 $* * * \cdot$ 清水洋一郎***・川嶋弘尚***

By Shuichi MATSUMOTO** • Hisafumi KOKUBUKATA*** • Yoichiro SHIMIZU*** · Hironao KAWASHIMA***

\section{1.はじめに}

わが国では高齢社会の進展による様々な影響が各分野 においてみられるようになっている。交通の分野におい ても、地方都市においては、モータリゼーションに端を 発した自動車中心の生活の中で、公共交通を用いた安定 したモビリティの確保が必要となっている。また、平成 14年に施行された改正道路運送法によりバス事業者の赤 字路線からの撤退が自由化されたことで、地方の過疎地 を中心に不採算路線からの撤退を申請する事業者が続出 している。しかし、バスは高齢者や学生など車を持たな い人々にとっては欠かすことのできない交通手段である ため、自治体などを中心に事業を継続するために経営の 再編を図る動きも見られる。

その中でもデマンドバスは、路線バスとタクシーとの 良い面を活かした乗り物であり、従来の路線バスの特徵 である定時・定路線の運行方法から、利用者の需要に応 じて時間と路線を柔軟に対応したサービスを提供するこ とが可能であるため注目されている。

デマンドバスは路線やダイヤ、バス停の設定に自由度 があるため、それらの組合せによって多様な運行形態が 存在する。林・湯沢1) の研究では、デマンドバスの運行 形態は大きく以下の 3 つ分類される。

\section{(1) 時刻固定・路線迂回型}

主要なバス路線と時刻表が予め決められており、利用 者からの予約がある場合のみバスルートを迂回する

(2) 時刻固定・路線非固定型

始発と終点のバス停および時刻表が決められており、 利用者からの予約に応じてバスルートを決定する

*キーワーズ : 計画手法論、経路選択、情報処理

**正員、博 (工) 、高知工科大学 総合研究所

(高知県香美市土佐山田町宮の口、

TEL0887-57-2760、FAX0887-57-2777)

***非員、工修、慶應義塾女子高等学校

***非員、工修、野村総合研究所

***正員、工博、慶應義塾大学 理工学部
(3) 時刻非固定・路線非固定型

決められた時刻と路線がなく、利用者の予約に応じて バスの運行を行う

デマンドバスについては、山口等 ${ }^{2)}$ が、IT 機能を用 いた高額かつ高ランニングコストのシステム導入が必要 な場合、自治体経営を圧迫する可能性を指摘している。 また、前述の林・湯沢によると、時刻固定・路線非固定 型や時刻非固定・路線非固定型のデマンドバスに関して は、コンピュータやGPSなどを活用したシステムが必要 なため、初期投資コストや通信費用がかかることが指摘 されている。一方、元田等の研究3) では、時刻固定・路 線迁回型に関しては、タクシー会社のノウハウや機材を 活用出来るため初期投資コストや運用コストを抑えるこ とが可能であることを示唆している。

デマンドバス事業も他の交通事業同様、車両や乗員 を固定的に確保しておく必要があり、上記の指摘もあわ せれば、デマンドバスの導入・運営費用は、必ずしも低 いわけではない。こうした状況を踏まえれば、地域の足 の確保など様々な理由により、デマンドバスを実際に導 入することになった場合、コスト削減と利便性の確保を 併せて検討し、効率的な運営がなされなければならない。

デマンドバスは需要に応じて運行するため、場合に よっては、一部の利用者の予約を拒否せざるをえなくな ることもある。このような問題点は、デマンドバスを効 率的に運行させることで解決できる場合もある。また、 運行を効率的にすることは、経費節減に繋がるため、デ マンドバス事業の維持には不可欠である。本稿では、デ マンドバス運行の効率性を高める一手法として、運用計 画作成の新たな手法を提案し、その手法を用いて行った 計算機実験を行う。

\section{2. 本研究の位置付け}

運行問題の効率化の観点から研究した先行事例とし ては、巡回セールスマン問題を中心とした最適化手法を 応用したものが多く、利用者に提供するサービスとデマ ンドバスの運行時間の加重和を最小化する配車配送方法 
を求めるDARP問題の解法を提案したAmaldi, et $\mathrm{al}^{4)}$ 、 利用者のサービス時間帯を早着、遅刻を禁止する hard t ime windowだけでなく、時間的制約を若干緩くした sof $\mathrm{t}$ time windowを用いて配車配送システムの近似解を求 めるアルゴリズムを提案した山内他 $)^{5}$ 、リアルタイム処 理により経路や時刻を完全に非固定にしたスケジューリ ングアルゴリズムを開発した大和他 ${ }^{6)}$ など理論や実用化 を視野にした実務的なものなど様々な研究が行われてい る。

一方、DARP (Dial A Ride Problem) では、各乗 客が指定した乗車・降車の時間帯制約と場所の要求を満 たしながら、同じ乗車定員をもつ複数の車両を用いて、 運行コストが最小になる運行計画を作成する。DAR P はNP （Non-deterministic Polynomial）困難な組合せ最 適化問題であり、厳密解法では解くことがきわめて難し いため、メタヒューリスティクス(汎用近似解法)を用い て解を探索することが多い。代表的なメタヒューリステ イクスには、染色体の遺伝子配列をモデル化し、配列の 変形による進化のメカニズムを確率的探索（Stochastic Search) に適用したGA法 (Genetic Algorithm) 、探索 において同じ解に戻ることを避ける工夫として一度行な った解の変形をある繰返し回数の間禁止する T S 法 (T abu Search) 、および本研究で用いるS A法（Simulated Annealing) などがある。

Cubillos et $\mathrm{al}^{7}$ は、GA法をDAR Pに応用した。ま た、Cordeau and Laporte ${ }^{8)}$ はT S法を用いて、以前に他 の配送計画問題を解く際に有効性が示されている手法 9)をD AR Pに応用し、車両の乗車定員および各乗客の 乗車または降車の時間帯制約に加えて、車両の最大稼働 時間、各乗客の最大乗車時間の制約を満たしながら、総 走行コストを最小にするアルゴリズムを提案した。

本研究では、SA法を用いてDAR Pを解く新たな

アルゴリズムを提案する。本研究は、デマンドバス運行 の基礎的研究に位置づけられ、デマンドバスの経路削減 に資するため、D A R P の新たな手法を提案するもので ある。

\section{DARPの新たな解法の提案}

（1）本研究で用いるアルゴリズム 本研究では、S A法を用いて、Cordeau and Laporte ${ }^{8)}$ が提示した例題を解くアルゴリズムを考案し、その性能 を比較した。S A法は、熱した固体を徐々に冷却すると、 完全格子をもつ構造に再結晶できるという、金属工学に おける原理を取り入れた確率的探索手法である。S A 法 では、繰返し計算における現在の解の近傍解のうちの 1 つをランダムに選んで次の解の候補とするが、評価関数 の值が改善する場合だけでなく、温度に対応する变数を
用い、その值に従う確率で、評価関数が一時的に改悪す る場合も次の解として受理する。解探索の初期では、温 度変数の值を大きく設定し、解の改悪を実行する確率を 高くして局所最適解に陥らないようにし、徐々に温度変 数の值を低くしていった探索の後期には、改悪の確率を 減らし大域的な最適解への収束を促す。

本手法では、Cordeau and Laporteの研究と同様に、以 下の評価関数によって解を評価して最小化を図る。

$$
\begin{aligned}
& \mathrm{f}(\mathrm{s})=\mathrm{c}(\mathrm{s})+\{\alpha \mathrm{q}(\mathrm{s})+\beta \mathrm{d}(\mathrm{s}) \\
& +\gamma \mathrm{w}(\mathrm{s})+\delta \mathrm{t}(\mathrm{s})+\varepsilon \mathrm{k}(\mathrm{s})\}
\end{aligned}
$$

ここで、 $\mathrm{c}(\mathrm{s})$ は解 $\mathrm{s}$ の総走行コスト、 $\mathrm{q}(\mathrm{s})$ は車両定員違反 量の合計、 d(s)は車両の稼動時間違反量の合計、w(s)は 乗客の時間帯制約違反量の合計、 $\mathrm{t}(\mathrm{s})$ は乗客の最大所要 時間違反量の合計、 $\mathrm{k}(\mathrm{s})$ は違反項目数の合計、 $\alpha 、 \beta$ 、 $\gamma 、 \delta 、 \varepsilon$ は各項の重み係数である。コスト項である $\mathrm{c}(\mathrm{s})$ は走行距離や走行時間といった最小化の目的であり、 また、c(s)以外のペナルティ項は問題の制約条件を満た さない違反量を測るもので、これを加算し最小化するこ とで制約条件を満たす最適解を求めようとする。ペナル ティ項の和が０でない解は実行不可能解であるが、ペナ ルティ項の重みが大きければ、f(s)を最小化することに より、実行可能解を得られる。目的関数における重み係 数は、予備計算実験における計算時間と得られる解の質 を勘案して、 $\alpha=1 、 \beta=\gamma=\delta=0.1 、 \varepsilon=5$ から始め、各 制約条件を個別にチェックし、満たしているものには その重み係数を $1 /(1+\lambda)$ 倍、満たしていないものには $1+\lambda$ 倍する。ただし、違反回数項は他の制約条件の状 態に依存するため、4つの制約の全てを満たしていれば、

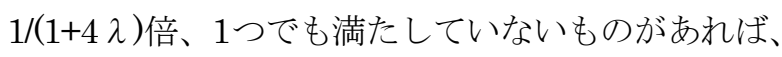
$1+\lambda$ 倍するものとした。ここで、 $\alpha, \beta, \gamma, \delta$ に対 する入は0.01、ยに対する入は0.04とした。

本提案手法に適用したS A法のアルゴリズムは、John son et al ${ }^{10)}$ によるパラメータ表記(大文字斜体のもの)を 用いて、以下のように表示できる。他の手法のように、 いくつかの凝った部分アルゴリズムを統合して大域的最 適化を図ることがないため本手法はきわめて単純な構成 になっている点が特徵である。

1 初期解 $x$ を生成

2 評価関数の值 $f$ を最良值 $f$ と として記録

3 同一温度での平均探索近傍数 $N$ を指定

4 温度変数 Tを INITTEMP に設定

5 試行回数 trials : $=0$, 解変形実施回数 changes :=0 に設定

6 近傍解のランダムな生成trials $:=$ trials +1

7 評価関数を改良するときは必ず、改悪するとき もTの值に従う確率で解変形を受理し、 
changes $:=$ changes +1 , 状態 $x$ の更新,

従来の最良值よりも良い解であるとき、最良值 f* の保存, 最良解 $x^{*}$ の保存

8 trials $<$ SIZEFACTOR $・ N$ かつ changes $<$ CUTOFF $\cdot N$ なら step 6 一

$9 \quad T:=T \cdot$ TEMPFACTOR

$10 T>$ INITTEMP / FINDIVISOR なら step 5 一

11 最良解 $x^{*}$ の出力

（2）ストリングモデルによる解の表現と最適解探索の ための解の変形方法

本研究で提案する手法では、Kokubugata et $\mathrm{al}^{11)}$ によっ て、積載制約のある複数の車両が倉庫から出発してデマ ンドのある顧客一荷物を配達して倉庫に戻る配送計画問 題（VR P）のために考案されたストリング形式のデー タモデルを応用して、複数の車両が利用者を訪問寸る順 番（D A R P の解）を表す。一般にVR P の解は各車両 のルートが車両の出発地かつ最終到着地（以下「デポ」 と記す）を中心に結びついた形をしている。利用者の利 用地点を示寸記号 “a h” とデポを示寸記号 “ 0 ” か ら成る各車両のルートを紐状に展開し、図1のように横 1列の1次元配列で表現したものがストリングモデルで ある。
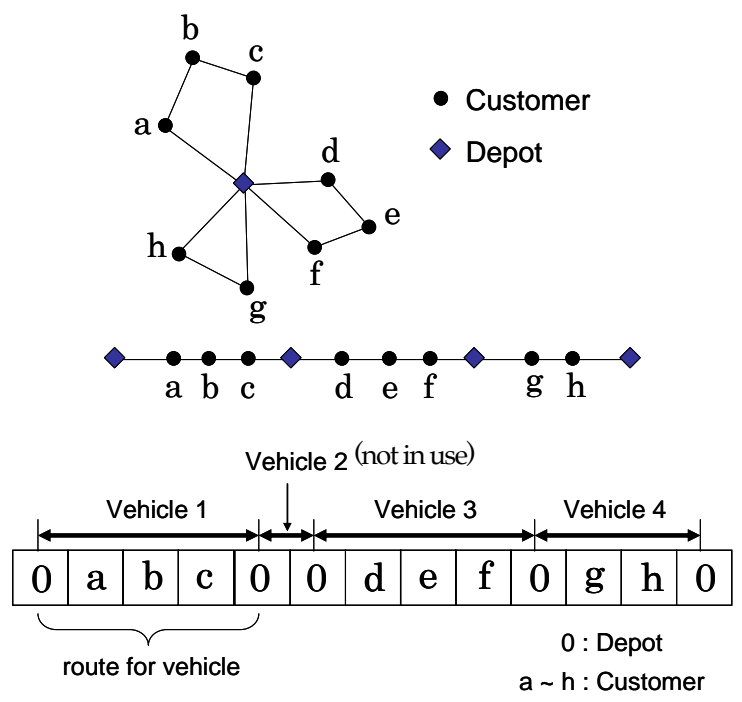

\section{図ー1 VRPのためのストリングモデル}

また、Kokubugata and Kawashima ${ }^{12)}$ が指摘するよう に、ストリングモデルは基本的なVR P だけでなく、車 両の回転利用が可能なケース、時間帯制約付きの問題な どに対しても応用可能であることが示されており、拡張 性、発展性の高、解の表現方法である。ストリングモデ ルに対して、両端以外の “0”を他の文字と同等に扱う 文字列の変形を行うことで、利用者の車両一の割り当て (クラスタリング）と巡回順の決定（ルーティング）を
同一の手順内で行うことができる。

次に、デマンドバスの運行計画をストリングモデル で表現する方法と、その解表現に確率的に適用する変形 方法である、削除・挿入と 1 対 1 交換について説明を行 う。デマンドバスの運行計画をストリングモデルで表現 する際には、利用者一人につき乗車と降車の 2 つ項目 を用意し、各利用者の乗車と降車のペアが必ず同じ車両 内に属すように、また乗車が降車より先に現れるように 作成しなければならない。最適解の探索における近傍解 の作成（解の変形）手順においては、代表的な近傍解作 成の手法でありそれぞれの変形効果が期待される削除・ 挿入 (図2) と 1 対 1 交換 (図 3 ) の2 種類の試行変形

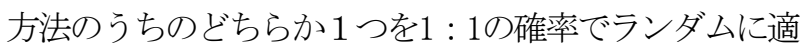
用寸る。

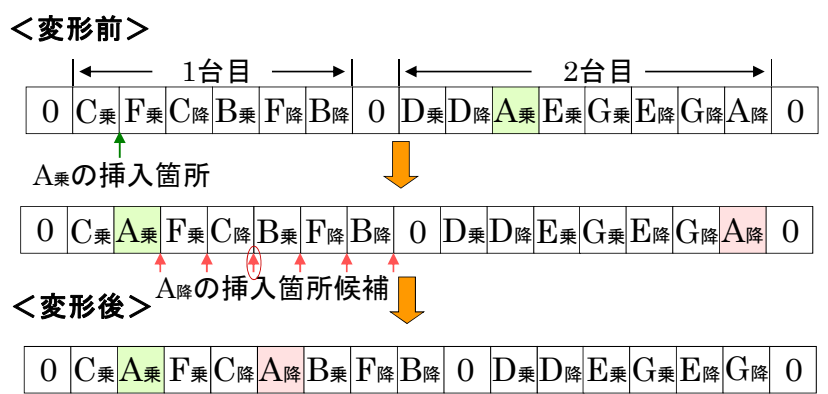

図ー2 DARPのためのストリングモデルと試行変形 (削除・挿入)

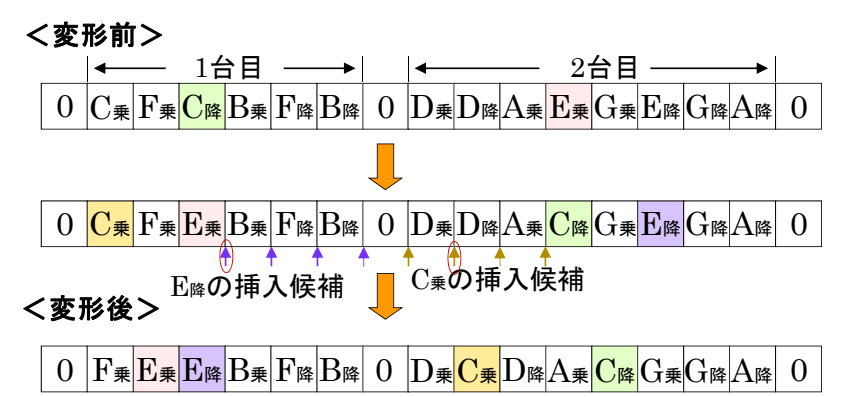

図ー3 D ARPのためのストリングモデルと試行変形 (1対 1交換)

削除・挿入では、まずストリングモデルの中からデ ポを示す “0” 以外から項目をランダムに選択する（図 $2: \mathrm{A}_{\text {乘 }}$ 。そして、その項目を現在の位置から取り除 き、ストリングモデル中のランダムに選ばれた箇所へ挿 入する (図 $2: \mathrm{C}_{\text {乘 }}$ 策の間)。しかし、このままで はD AR Pにおける「各利用者の乗車と降車のペアが必 ず同じ車両内に属する」、「乗車が降車より先に現れ る」といら制約が保証されないので、移動した項目の対 となる項目（図 2：A降 を同車両内の先行関係を壊さ

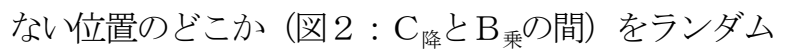
に選び、そこへ移動することで可能な変形が完了する。 
また、1対1交換については、まずストリングモデルの 中からデポを示す “0” 以外から項目を2つランダムに

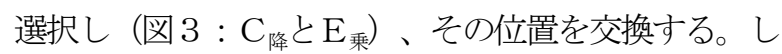
かし、このままではペアリングと先行関係が保証されな いので、交換した項目のそれぞれの対となる項目（図 3： $\mathrm{C}_{\text {乘之 }} \mathrm{E}_{\text {降 }}$ をを同車両内の先行関係を壊さない位置

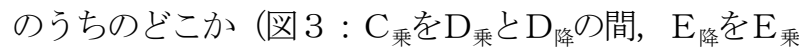

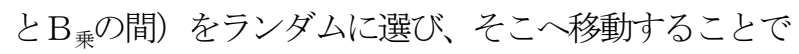
DAR Pでの変形が完了寸る。

（3）解の質向上に関する工夫

本研究では、解の質の向上のために、乗車と降車の ペアデマンド挿入箅所を制限する工夫と、解探索の途中

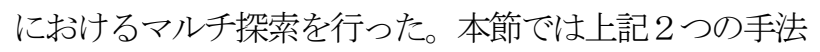
に関して説明を行う。

a) ペアデマンド挿入箇所の制限

2 節で説明した削除・挿入と 1 対 1 交換のいずれの場 合でも、乗車項目を動かした際はペアとなる降車項目を、 降車項目を動かした際はペアとなる乗車項目を続けて移 動させるが、この乗車と降車の両項目の位置がストリグ モデル内で離れすぎていると所要時間が長くなりすぎて 最大所要時間制約を大きく壞してしまうことになる。そ こで、ペアとなる項目を移動する際には、所要時間が長 くなり過ぎない範囲内でランダムに挿入箇所を選択する こととする。具体的には、利用者の所要時間が最大所要 時間 $L$ に任意定数 $\tau$ を加えた時間を越えない範井を挿 入䇢所の候補とし、越える範囲は対象から外す。

例として挿入箇所制限のイメージを図 4 として示す。

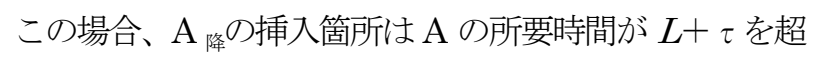

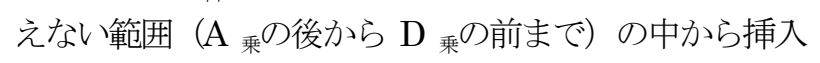
箇所をランダムに選択することになる。

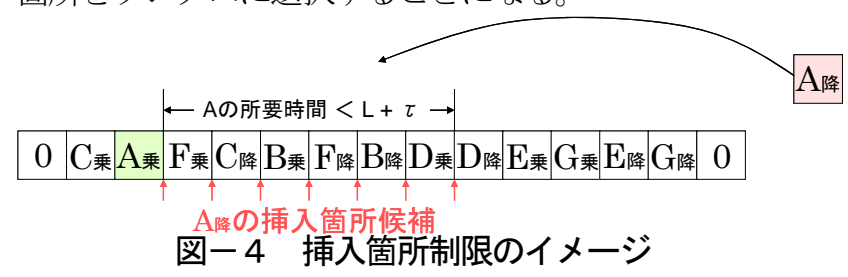

この取り組みには、SA法のアルゴリズムにて遷移を 棄却されるような制約条件を大きく破る近傍解の生成を 未然に防ぐ働きがある。そのため、限られた計算時間の 中で状態遷移の回数を増やすことができ、得られる解の 質の向上が期待できる。

b）解探索途中におけるマルチ探索

試行変形や SA 法の受理判定は確率論的方法であるの で、発生した乱数によって探索の動きは大きく異なる。 そこで、解探索の過程において、得られる解の質に大き
な影響を与えると考えられる温度帯で探索を $k$ 個に分岐 させ、その中で最も良かった実行可能解から探索を再開 するという方法を取り入れる。これにより、良い解に行 き着きそうな領域を積極的に探索することになる。

<高温>

<低温>

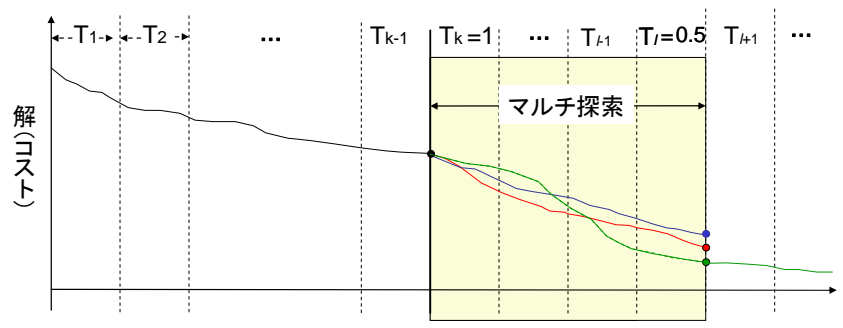

遷移回数

図—5 アルゴリズム途中のマルチ探索のイメージ

\section{4. 提案手法の評価}

\section{（1）先行手法との性能比較実験}

本研究では前節で提案した手法の性能を評価するた め、他のメタヒューリスティックであるT S 法を用いた D A R P として代表的なCordeau and Laporteが提示した 例題の計算結果 との比較実験を行う。Cordeau and Laporteは、モントリオール市におけるデータをもとに D A R P の例題20問(R1a～R10b)を作成し、Web上に掲 載している ${ }^{13)}$ 。その概要を表 1 に示す。

\section{表-1 Cordeau and Laportelによる例題(20問)の概要}

\begin{tabular}{|l|l|}
\hline 利用方法 & 事前予約 \\
\hline 利用者数 & $24 \sim 144$ 人 \\
\hline 車両数 & $3 \sim 13$ 台 \\
\hline 目的関数 & 走行コスト最小化 \\
\hline 制約条件 & $\begin{array}{l}\text { 車両定員・各乗客の乗車または降 } \\
\text { 車の希望時間帯・乗客の最大乗車 } \\
\text { 時間・車両の最大稼働時間 }\end{array}$ \\
\hline ネットワーク & ユークリッド平面上の完全グラフ \\
\hline
\end{tabular}

この例題では、 $n$ 人の利用者の乗車地点と降車地点は ユークリッド平面[-10,10] ${ }^{2}$ 上にランダムに発生されてお り、デポの位置は全ノードの重心となっている。2地点 間の走行コスト $c_{i j}$ および移動時間はユークリッド距離に 等しくしている。本例題の目的は全ての車両の走行コス 卜の合計を最小化することであり、その際に各乗客の乗 車または降車の時間帯、最大乗車時間、車両最大稼働時 間、乗車定員が制約条件となる。

なお、提案手法のS A パラメタ值は、Johnson et $\mathrm{al}^{10)}$ の研究において有効とされている值を参考にして設定し た。提案手法ではT S 法と異なり確率的探索を行うので 
毎回計算結果が異なるため、各問題に対して 5 回ずつ計 算を行なって、平均と最良の場合の性能を調べた。

Cordeau and Laporte による最良解は、T S 法の解の更新 回数が $10^{5}$ 回の場合で得られていたので、本研究でも計 算時間（問題により計算時間が 1000〜60000 秒）が概ね 等しくなるようにS Aのパラメタを設定して実験（以下 「計算時間大」と記す）を行った。Cordeau and Laporte が最良解として報告した解のコストに対する、本手法を 用いて算出した平均解と最良解のコストの比を図 3 に示 す。本手法による平均解と最良解のコスト比の差の例題 50 問における平均值は、それぞれ+0.84\%と+0.14\%で ある。なお、本研究の計算実験は core 2 duo 4300 (1.8GHz) の Windows PC 上、Cordeau and Laporte の手 法は Pentium $4(2.0 \mathrm{GHz})$ の Windows PC 上で害行さ れているため単純に比較することはできないが、本手法 の平均計算時間は 20,329 秒、Cordeau and Laporte では 26,817 秒であった。

図3に示寸ように、提案手法の方が良い結果を出し た問題、逆に先行手法の方が良い結果を出していた問 題の双方が見られるが、全体として両手法の解の質はほ ぼ同等と捉えることができる。また、提案手法では全 20 問中 7 問で先行手法で報告されている最良解を更新 し、2 問で報告されている最良解と一致する結果を得た。 次に、実用面を考慮に入れ、計算時間が約 $1 / 10$ とな る計算実験（以下「計算時間中」と記す）、そしてさら に計算時間が約 $1 / 100$ となる計算実験（以下「計算時間 小」と記す）を行い、本手法で得られた計算時間大の最 良解の值に対するコストの比の増加を計算した（表一

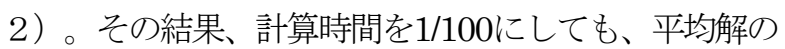
コストは、計算時間大の場合の最良解と比較して約 $8 \%$ 増加するだけであることがわかった。
表一2 計算時間を短縮した場合のコスト比の増加 (全20問の平均值)

\begin{tabular}{|c|c|c|c|}
\hline & 最良解 & 平均解 & $\begin{array}{c}\text { 平均計算時間 } \\
\text { (秒) }\end{array}$ \\
\hline 計算時間大 & $0.00 \%$ & $+0.76 \%$ & 26817 \\
\hline 計算時間中 & $+2.02 \%$ & $+3.21 \%$ & 2855 \\
\hline 計算時間小 & $+6.07 \%$ & $+8.22 \%$ & 275 \\
\hline
\end{tabular}

以上のように、計算時間を十分にとれば提案手法は今ま でに報告されている最良解を更新し、また全体的にも先 行研究の結果に匹敵する結果が得られた。また、計算時 間を数分とするような計算実験においても、計算時間大 の場合の最良解よりコストが約 $8 \%$ 増加する解を平均的 に得られることわかった。したがって、本提案手法はD AR P の近似解法として実用上十分な性能を有している ものと考えられる。

（2）運用データをモデルとした実験

本手法の現実問題への適応可能性を検討するために、 実際に運営されているデマンドバスの運行データをモデ ルに計算実験を行った。対象としたデマンドバス事業 は高知県 “中村まちバス”である。

中村まちバスは約 $5 \mathrm{~km}$ 四方の営業区域に57箇所のバス 停を構え、15人乗りバス 1 台で運行されている。また営 業時間は8:30〜11:00（時間帯 1），12:00～14:30（時 間帯 2)，16:00〜18:00（時間帯 3）と3つのタームが 設けられており、利用者は当日の電話予約によりデマン ドバスを利用することができる。本実験では、2007年12 月14日 (金)の運行データを利用寸る。当日の利用状況は、 時間帯 1 が 19 人、時間帯 2 が 15 人、時間帯 3 が9人であ る。計算機実験の結果を表 3 に示す。

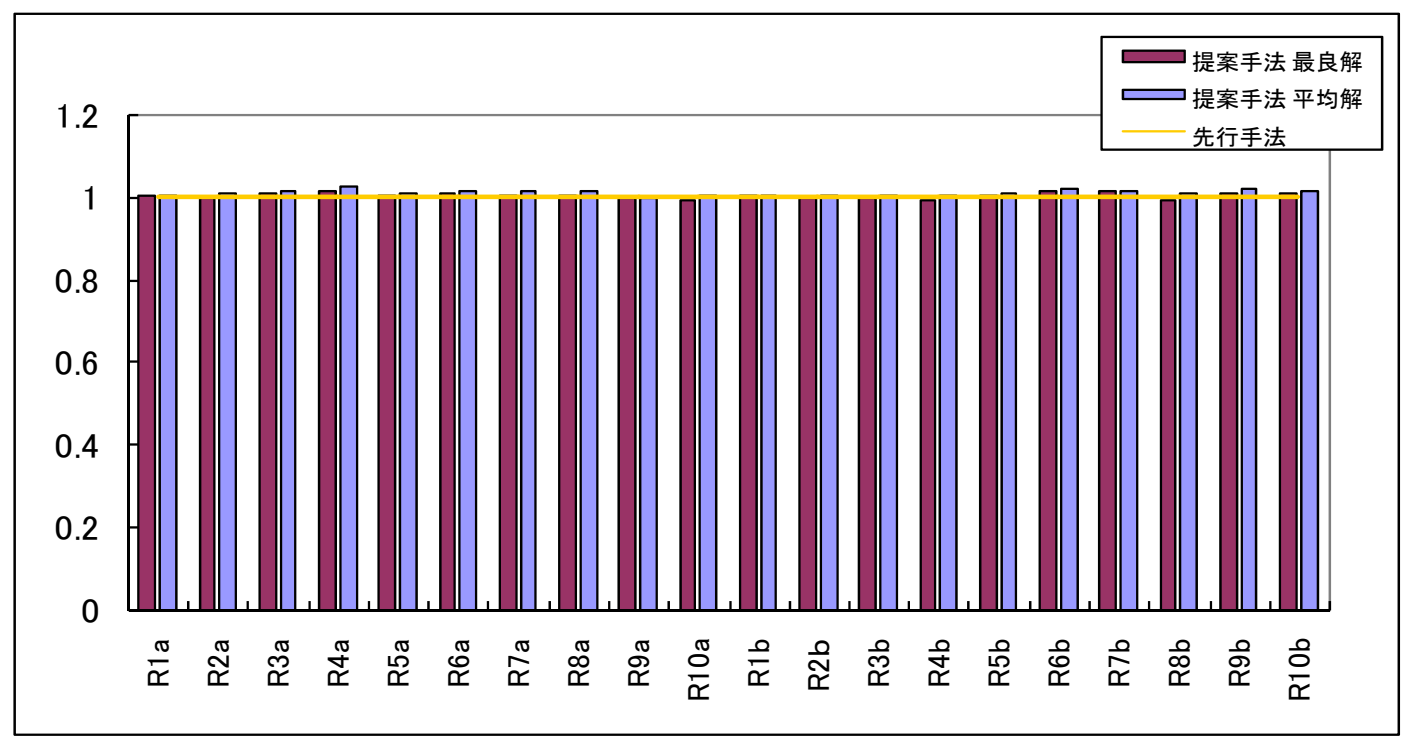

図－3 手法の比較実験（計算時間大）の結果 


\section{表-3 応用実験結果}

\begin{tabular}{|c|c|c|c|}
\hline & 実測值 & 実験結果 & 改善効果 \\
\hline 時間帯 1 & $34493 \mathrm{~m}$ & $30908 \mathrm{~m}$ & $10.4 \%$ \\
\hline 時間帯 2 & $26330 \mathrm{~m}$ & $22274 \mathrm{~m}$ & $15.4 \%$ \\
\hline 時間帯 3 & $10835 \mathrm{~m}$ & $10499 \mathrm{~m}$ & $3.1 \%$ \\
\hline
\end{tabular}

本実験では、交通状況など、現実とまったく同じ条件の 下で計算実験が行われたわけではないが、本手法により 平均して $10 \%$ ほど害測值より走行コストの少ないルート を作成することができた。計算時間は、利用者が最も多 い時間帯 1 で平均250秒である。この結果より、提案し た手法が現実のデマンドバス運行計画の作成においても 経路削減効果を発揮することが示唆された。

\section{5.おわりに}

本研究では、DARPを活用しデマンドバスなどに適用 可能な新たな手法を開発した。また、本手法を用いて計 算機実験を行ったところ、先行研究と同等の結果が得ら れ、その性能が保証された。また、実際のデマンドバス の運行データをもとに行った実験においても良好な結果 が得られ、本手法が現実問題に対しても効果的であるこ とが示唆された。

この手法は、ストリングモデルとSA法を用いた、極 めて単純なデータモデルとアルゴリズムにより実現され るものである。

デマンドバスにおいて、このような効率的な運行計画 を導くアルゴリズムを活用することで、より良いサービ スを提供できる配送計画の作成に寄与できると考えられ る。またデマンドバスの導入の可能性を検討寸る際のツ ールとしての活用を考えている。

\section{謝辞}

本研究にあたっては、高知県でデマンドバス事業を 行っている西南交通侏の皆様に現地の調査協力を頂きま した。また論文執筆にあたって帝塚山大学中村先生より 様々な有用なご意見を頂きました。ここに記して感謝の 意を申し上げたい。

\section{参考文献}

1）林光伸, 湯沢昭: デマンドバス導入のための需要 予測と運行形態の評価に関する一考察, 都市計画 論文集，第24-3号、CD-ROM， 2006.

2）山口善英，元田良孝，宇佐美誠史，古関潤 : デ マンドバスはITか。雫石あねつこバスの事例研究,
土木計画学研究講演集, 第33巻, CD-ROM, 2006.

3）元田良孝, 若林武文, 山口善英: 雫石町フレキシ ブルバスの運行について，土木計画学研究講演集， 第29巻, CD-ROM, 2003.

4) Amaldi, et. al :A dial-a-ride to be implemented in a suburban area of Milan, 7th World Congress on ITS, CD-ROM, 2000.

5 ）山内将平, 谷口栄一, 山田忠史, 中村有克 : ラベ リングアルゴリズムを用いた時間枠制約付き配車 配送計画問題の解法に関する研究，土木計画学研 究講演集，第36巻，CD-ROM， 2007.

6）大和裕幸, 坪内孝太, 稗方和夫 : オンデマンドバ スのためのリアルタイムスケジューリングアルゴ リズムとシミュレーションによるその評価，運輸 政策研究，第10巻第4号, pp. 2-10, 2008.

7) Cubillos, C., Rodriguez, N. and Crawford, B. : A Study on Genetic Algorithms for the DARP Proble m, IWINAC 2007 Part 1 LNCS 4527 pp. 498-507, 20 07

8) Cordeau, J. F. and Laporte, G : A tabu search $h$ euristic for the static multi-vehicle dial-a -ride problem, Transportation Research, Part B 37, pp. 579-594, 2003.

9) Cordeau, J. F., Laporte, G. and Mercier, A. : A uni fied tabu search heuristic for vehicle routing problems with time windows, Journal of the Oper ational Research Society 52, pp. 928-936. 2001

$10)$ Johnson, D. S., Aragon, C. R., McGeoch, L. A., Sche von, $C$ :Optimization by simulated annealing An e xperimental evaluation, part II, graph coloring and number partitioning, Operations Research, Vol. 39, pp. 378-406, 1991.

11 ) Kokubugata, $\mathrm{H}$, Itoyama, $\mathrm{H}$ and Kawashima, $\mathrm{H}: \mathrm{V}$ ehicle routing methods for city logistics ope rations, Preprint for IFAC Symposium on Trans portation Systems, pp. 727-732, 1997.

12 ) Kokubugata, H. and Kawashima, $H$ :Application of simulated annealing to routing problems $i$ n city logistics, in 'Simulated Annealing', Cher Ming Tan (Ed. ), I-Tech Education and Pub lishing, Vienna, pp.131-154, 2008

13 ) CHAIRE DE RECHERCHE DU CANADA EN DISTRIBUTI QUE : http://neumann. hec. ca/chairedistributi que/ 
デマンドバス配車配送計画の実用的解法*

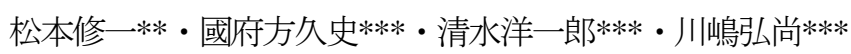

デマンドバスの運行計画作成にはD A R P といらルーティング問題の解決手法が適用できる。本研究では、筆者ら が考案したストリングモデルとS A法を活用した解法を活用して、既存のD A R P の最良解を更新する効率的な運行 ルートを策定できる可能性を示唆した。また中村まちバスを対象に本手法の導入効果算定を行った結果、10\%程度の 運行経路削減効果が観察された。このことから提案手法を活用したデマンドバス運行計画を活用することで効率的な 運行計画の作成が期待される。

\section{A Practical Approach to Demand Bus Routing Problem*}

By Shuichi MATSUMOTO** • Hisafumi KOKUBUKATA*** • Yoichiro SHIMIZU*** • Hironao KAWASHIMA*** Solution method for routing problems called "dial-a-ride problems" (DARP) can be applied to the creation of service plans for on-demand buses. This study suggests that it may be possible to formulate more efficient operating routes that improve on the existing best solution for DARP, by using a solution method devised by the authors. The effectiveness of adopting this method was estimated by looking at the Nakamura-machi Bus, and the observed effect was a roughly $10 \%$ reduction in operating routes. This result shows that the proposed method is likely to be effective for reducing costs when used for on-demand bus service planning. 